\title{
Pemetaan Kawasan Lahan Pertanian Pangan Berkelanjutan di Kuta Utara dan Mengwi Berbasis Penginderaan Jauh dan Sistem Informasi Geografis
}

\author{
KARTIKA DEWI OKTAFIANTI, INDAYATI LANYA*), DAN NI MADE \\ TRIGUNASIH
}

\author{
Program Studi Agroekoteknologi Fakultas Pertanian Universitas Udayana \\ Jl. PB. Sudirman Denpasar 80231 Bali \\ ${ }^{*}$ E-mail: indahnet@yahoo.co.id
}

\begin{abstract}
Mapping of Sustainable Food Agricultural Land at North Kuta and Mengwi Districts Based on Remote Sensing and Geographical Information System. Sustainable Food Agricultural Land (LP2B) is a field of agricultural land designated to be protected and developed consistently in order to produce staple food for national food independence, resilience and sovereignty. The Badung Regency Government has determined the area and location of LP2B but it has not been accompanied by a spatial information map. This study aims to map subak rice fields in 2019 as well as mapping of LP2B based on the physical conditions of the area and the environment in North Kuta and Mengwi Districts based on remote sensing and GIS. The method used consists of image interpretation, field survey and numerical classification. The results showed that the distribution of subak rice fields in North Kuta and Mengwi Districts was 4967.22 ha. The distribution of rice fields in North Kuta District is 850.15 ha and in Mengwi District is $4117.07 \mathrm{ha}$. In the classification of LP2B areas, the recommended area is model 1 (234.88 ha), model 2 (939.76 ha) and model 3 (2048.63 ha). The recommendation areas are in model 1 (1489.91 ha), model 2 (1101.52 ha) and model 3 (2047.53 ha). The conditional recommendation area is in model 1 (2969.50 ha), model 2 (2048.49 ha) and model 3 (873.39 ha). Not recommended area in model 1 (270.81 ha), model 2 (875.33 ha) and model 3 (0 ha).
\end{abstract}

Keywords: mapping, sustainable food agricultural land, geographic information system

\section{PENDAHULUAN}

Peningkatan jumlah penduduk

berbanding lurus dengan kebutuhan

persediaan pangan, dimana pangan dihasilkan dari lahan pertanian, sedangkan lahan pertanian sudah banyak yang terkonversi menjadi pemukiman atau penggunaan lahan nonpertanian lainnya. Terjadinya alih fungsi lahan pertanian yang tak terkendali akan mengurangi luasan 


\section{KARTIKA DEWI OKTAFIANTI et al. Pemetaan Kawasan Lahan Pertanian Pangan...}

lahan pertanian secara signifikan yang dapat mengancam ketahanan pangan baik secara lokal maupun nasional.

Berdasarkan penelitian Lanya $d k k$. (2015), dampak alih fungsi lahan sangat berpengaruh terhadap persediaan pangan di Kota Denpasar. Penelitian tersebut mendapatkan hasil analisis proyeksi luas lahan sawah, proyeksi penduduk, persediaan pangan dan kebutuhan pangan tahun 2020, 2030, 2040 dan 2050 di Kota Denpasar yang menunjukkan bahwa luas sawah dan persediaan pangan semakin menurun menurut deret hitung, berbanding terbalik dengan pertumbuhan penduduk dan kebutuhan pangan semakin meningkat mengikuti deret ukur.

Menurut data BPS Kabupaten Badung (2019), luas lahan pertanian di Kabupaten Badung yaitu 19.111 ha, dengan lahan sawah seluas 9.935,84 ha. Tahun 2019, luas lahan sawah di Kabupaten Badung yaitu 9.912,40 ha, mengalami penurunan sebesar 23,44 ha. Tahun 2015 hingga tahun 2019, Kabupaten Badung mengalami penurunan luas lahan sawah seluas 115,32 ha. Kecamatan Kuta Utara merupakan kecamatan yang mengalami penurunan luas lahan sawah tertinggi selama lima tahun tersebut, dan Mengwi tertinggi setelah Petang, yaitu masing-masing berkurang seluas 56,81 ha dan 14 ha dengan rata-rata penurunan per tahun yaitu 11,36 ha dan 2,8 ha.

Pemerintah menetapakan UndangUndang Nomor 41 Tahun 2009 tentang Perlindungan Lahan Pertanian Pangan Berkelanjutan (PLP2B) dalam rangka pengendalian alih fungsi lahan pertanian pangan. Peraturan tersebut mengatur bahwa penetapan kawasan LP2B kabupaten/kota ditetapkan dalam Rencana Tata Ruang Wilayah Kabupaten/Kota.

Pemerintah Kabupaten Badung dalam Rencana Tata Ruang Wilayah Kabupaten Badung Tahun 2013 - 2033 dan Perda Nomor 8 Tahun 2019 tentang Perlindungan LP2B telah menyebutkan bahwa penetapan pencapaian target luas Lahan Pertanian Pangan Berkelanjutan sekurang-kurangnya 90\% dari luas lahan pertanian pangan yang ada sejak ditetapkannya peraturan ini. Namun penetapan target luas dan lokasi lahan tersebut belum disertai dengan peta informasi spasial mengenai LP2B. Penelitian tentang pemetaan LP2B di Provinsi Bali telah dilakukan oleh Lanya $d k k .(2015)$.

Berdasarkan permasalahan di atas, maka penulis melakukan penelitian dengan judul "Pemetaan Kawasan Lahan Pertanian Pangan Berkelanjutan di Kecamatan Kuta 
Utara dan Mengwi berbasis Penginderaan Jauh dan Sistem Informasi Geografis". Adapun tujuan dari penelitian ini yaitu pemetaan lahan sawah subak tahun 2019 di Kecamatan Kuta Utara dan Mengwi serta pemetaan LP2B berdasarkan kondisi fisik wilayah dan lingkungan di Kecamatan Kuta Utara dan Kecamatan Mengwi berbasis Penginderaan Jauh dan Sistem Informasi Geografis dalam berbagai permodelan.

\section{BAHAN DAN METODE}

Penelitian ini dilakukan pada April 2020 sampai Oktober 2020 di Kecamatan Kuta Utara dan Kecamatan Mengwi, Kabupaten Badung, mulai dari penyusunan proposal hingga pembuatan peta. Secara geografis, Kecamatan Kuta Utara dan Mengwi berada antara 08 26’36” $08^{\circ} 41^{\prime} 03$ ' Lintang Selatan dan $115^{\circ} 05^{\prime} 55^{\prime}$ " - 115¹2’20” Bujur Timur, dengan luas wilayah masing-masing sebesar $33,86 \mathrm{~km}^{2}$ dan $82 \mathrm{~km}^{2}$. Secara administrasi, lokasi penelitian berbatasan dengan Kabupaten Tabanan di sebelah Utara, Kecamatan Abiansemal dan Kota Denpasar di sebelah Timur, Kecamatan Kuta di sebelah Selatan dan Samudra Hindia serta Kabupaten Tabanan di sebelah Barat.

Alat-alat yang digunakan dalam penelitian ini antara lain seperangkat komputer/laptop, Software QGIS 3.10.6, Software ArcGIS 10.4, kamera/Handphone dan alat tulis. Bahan-bahan yang digunakan dalam penelitian ini yaitu Citra Satelit Resolusi Tinggi (CSRT) Kecamatan Kuta Utara dan Mengwi (Worldview tahun 2019dengan resolusi spasial 1,24 m (multispektral) dan 0,5 m (pankromatrik)), Peta Rupa Bumi Indonesia (RBI) Digital Kecamatan Kuta Utara dan Mengwi, peta administrasi Kecamatan Kuta Utara dan Mengwi, peta-peta penunjang LP2B (peta DAS, peta penggunaan lahan, peta kesesuaian lahan sawah dengan RTRW, peta jenis pengairan, peta bentuk wilayah/ kemiringan lereng, peta ketinggian tempat, peta curah hujan, peta kesesuaian lahan agroekosistem, peta produktivitas, peta jarak dari pusat kota, peta luas lahan minimal) dan data statistik Kabupaten Badung tahun 2019.

Metode yang digunakan terdiri atas interpretasi citra, survei lapang dan klasifikasi numerik. Metode klasifikasi numerik mengacu pada klasifikasi dalam penelitian Lanya $d k k$. (2015) dan Trigunasih (2017). Adapun tahapan pelaksanaan penelitian meliputi studi pustaka, interpretasi citra, survei lapang dan analisis peta-peta. Studi pustaka dilakukan untuk menghimpun informasi yang relavan 


\section{KARTIKA DEWI OKTAFIANTI et al. Pemetaan Kawasan Lahan Pertanian Pangan...}

dengan penelitian yang akan dilakukan, seperti jurnal-jurnal penelitian, data hasil penelitian terdahulu, peraturan-peraturan perundang-undangan, data statistik dan informasi-informasi lainnya.

Interpretasi jenis penggunaan lahan sawah dari citra satelit secara visual menggunakan 9 unsur interpretasi, yaitu bentuk, ukuran, warna, kekontrasan, tekstur, pola, bayangan, lokasi dan asosiasi. Citra yang digunakan dalam interpretasi yaitu citra Worldview Kabupaten Badung tahun 2019. Interpretasi citra dilakukan dengan menginput dan meregistrasi citra tersebut ke dalam software QGIS 2.18.0. Dilanjutkan dengan mengidentifikasi dan mendelinieasi lahan sawah berupa poligon melalui digitasi. Dalam menginterpretasi, lahan sawah dapat dicirikan berupa penampakan petakan-petakan dengan pola teratur. Hasil interpretasi citra ialah berupa peta tentatif penggunaan lahan. Peta ini digunakan untuk rencana pengamatan (pengecekan jenis penggunaan lahan) pada saat pengamatan lapangan.

Survei lapang ditujukan untuk pengamatan hasil interpretasi peta jenis penggunaan lahan pada citra satelit dengan kondisi sebenarnya. Selanjutnya dilakukan reinterpretasi dan digitasi peta jenis penggunaan lahan sawah sesuai dengan hasil survei lapang.

Data spasial peta-peta penunjang kawasan LP2B berupa garis dan poligon didigitasi dengan menggunakan perangkat lunak QGIS 3.10.6. Peta-peta penunjang kawasan LP2B antara lain (1) kesesuaian lokasi sawah dengan RTRW, penggunaan lahan, (3) posisi subak dalam Daerah Aliran Sungai, (4) jenis pengairan, (5) curah hujan, (6) bentuk wilayah, (7) tinggi tempat, (8) kesesuaian lahan agrekosistem padi sawah, (9) produktivitas lahan, (10) jarak dari pusat pariwisata dan (11) luas minimal. Masing Parameter dibobot (1-11) dan diskoring (1-3) untuk dinilai dan diklasifikasikan secara kuantitatif. Kemudian seluruh parameter dilakukan overlay/intersect .

Hasil overlay digital seluruh parameter menghasilkan skor total di setiap sebaran data. Sebaran data dapat menunjukkan nilai maksimum, minimum, rata-rata, dan standard deviasi. Data hasil overlay dapat dikelompokkan atau dibuat ring populasi data berdasarkan nilai skor total.

Klasifikasi lahan subak dalam 3 (tiga) permodelan. Adapun permodelan didasarkan pada nilai populasi, maksmum, minimum, nilai rata rata dan standar 
deviasi. Masing-masing parameter dan permodelan disusun dengan kaidah kartografi kemudian diperoleh peta-peta parameter serta peta rekomendasi LP2B untuk setiap permodelan. Klasifikasi rekomendasi LP2B dibedakan ke dalam 4 (empat) kelompok, yaitu sangat direkomendasikan, rekomendasi, rekomendasi bersyarat dan tidak direkomendasikan.

\section{HASIL DAN PEMBAHASAN}

Sebaran lahan sawah subak di

\section{Kecamatan Kuta Utara dan Mengwi}

Peta sebaran lahan sawah pada tahun 2019 di masing-masing subak dihasilkan dari analisis Citra Satelit WorldView di Kecamatan Kuta Utara dan Mengwi liputan tahun 2019. Menginterpretasi cita satelit, lahan sawah dapat dicirikan berupa penampakan petakan-petakan dengan pola teratur, unsur warna bervariasi dari terang sampai hujau muda menunjukkan fase pertumbuhan padi. Hal ini sesuai dengan penelitian Lanya (2016) dan Trigunasih (2017)

Tingkat ketelitian interpretasi citra satelit adalah $95 \%$, dihitung dengan membandingkan jumlah sampel yang sesuai kondisi lapangan dengan jumlah sampel hasil interpretasi tentatif. Tingkat ketelitian interpretasi citra satelit dalam penelitian lebih rendah dibandingkan penelitian pemetaan lahan sawah subak di Kabupaten Gianyar oleh Lanya dan Subadiyasa (2016) dengan tingkat akurasi 99\%. Suarjaya $d k k$. (2017) dan Feronika dkk. (2017) dalam penelitiannya menggunakan teknologi penginderaan jauh dan SIG dalam pemetaan lahan sawah subak di Kecamatan Kuta Utara dan Kuta serta Kecamatan Mengwi.

Berdasarkan hasil analisis citra satelit dan survei lapang, luas lahan sawah subak di Kecamatan Kuta Utara dan Mengwi yaitu 4.967,22 ha, Kecamatan Kuta Utara seluas 850,15 ha dan Kecamatan Mengwi seluas 4.117,07 ha. Subak terluas yaitu Subak Cemagi Let $(327,65$ ha) dan terendah yaitu Subak Batan Asem seluas 2,89 ha yang berada di Desa Mengwitani. Data spasial sebaran lahan sawah tahun 2019 di masingmasing subak yang ada di Kecamatan Kuta Utara dan Kecamatan Mengwi disajikan pada Gambar 1.

\section{Zonasi Lahan Sawah di Kecamatan Kuta Utara dan Mengwi}

Hasil klasifikasi numerik diperoleh data nilai maksimum, minimum, rata-rata dan standar deviasi. Hasil tersebut dikelompokkan atau dibuat ring populasi berdasarkan nilai total. Data ring populasi 


\section{KARTIKA DEWI OKTAFIANTI et al. Pemetaan Kawasan Lahan Pertanian Pangan...}

digunakan untuk klasifikasi zonasi lahan subak dalam permodelan. Permodelan dengan rumus standar deviasi menghasilkan klasifikasi LP2B antara lain sangat rekomendasi, rekomendasi, rekomendasi bersyarat dan tidak direkomendasikan sebagai LP2B. Data luas lahan sawah subak hasil klasifikasi dalam berbagai permodelan disajikan pada Tabel 2.

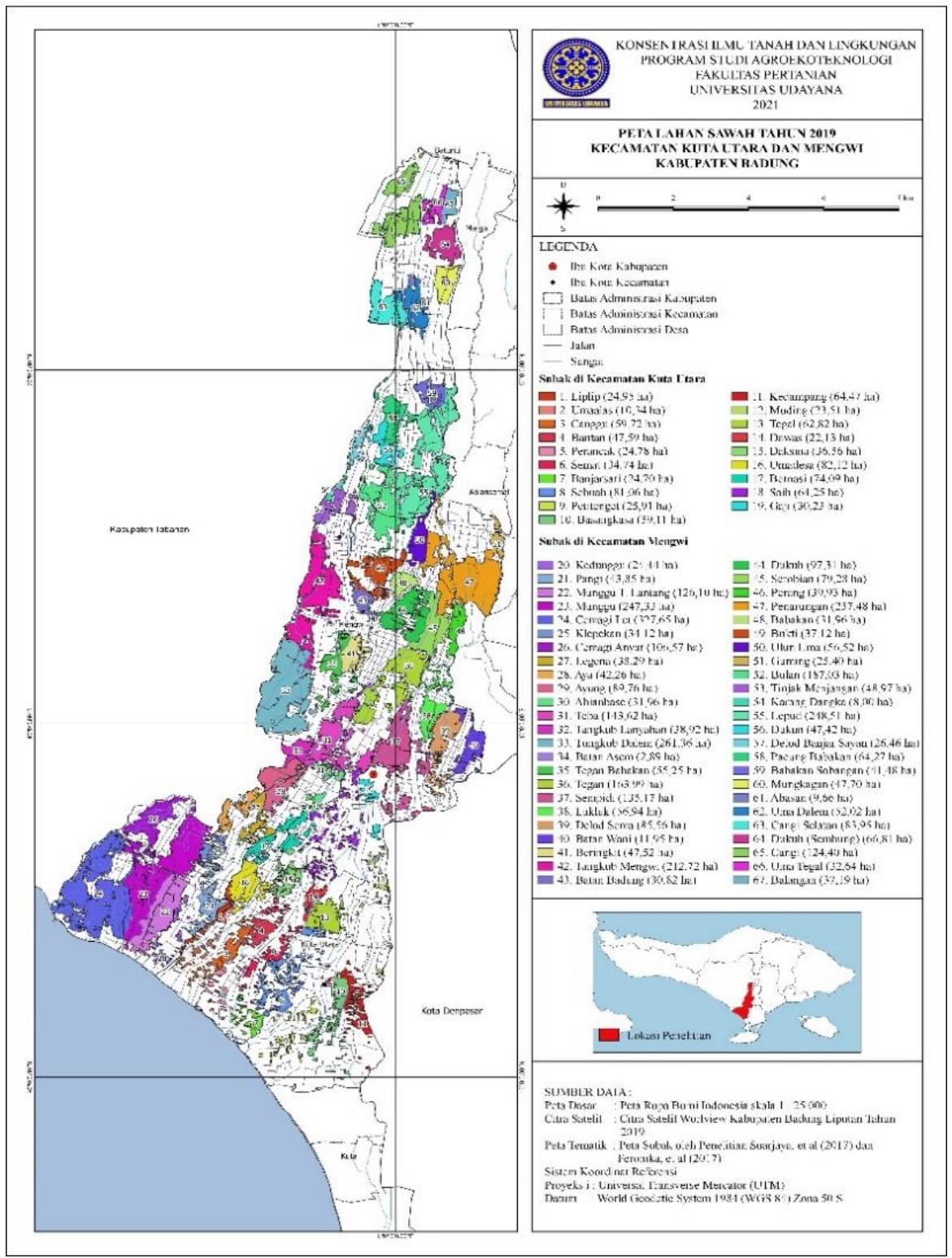

Gambar 1. Peta Lahan Sawah Subak di Kecamatan Kuta Utara dan Mengwi Tahun 2019 
Agrotrop : Journal on Agriculture Science, 11 (2): 176 - 188 (2021)

Tabel 2. Luas Klasfikasi Lahan Sawah yang Direkomendasikan sebagai LP2B dalam Berbagai Permodelan

\begin{tabular}{ccccc}
\hline $\begin{array}{c}\text { Kecamatan/ } \\
\text { Model }\end{array}$ & $\begin{array}{c}\text { Sangat } \\
\text { Rekomendasi }\end{array}$ & $\begin{array}{c}\text { Luas Klasifikasi Lahan Sawah (Ha) } \\
\text { Rekomendasi }\end{array}$ & $\begin{array}{c}\text { Rekomendasi } \\
\text { Bersyarat }\end{array}$ & $\begin{array}{c}\text { Tidak } \\
\text { Direkomendasi }\end{array}$ \\
\hline $\begin{array}{c}\text { I. Kuta Utara } \\
\text { Model 1 }\end{array}$ & 0 & 0 & 714,48 & 138,02 \\
Model 2 & 0 & 0 & 484,69 & 365,46 \\
Model 3 & 0 & 484,69 & 365,46 & 0 \\
II. Mengwi & & & & \\
Model 1 & 234,88 & $1.489,91$ & $2.255,04$ & 132,75 \\
Model 2 & 939,76 & $1.101,52$ & $1.563,8$ & 507,51 \\
Model 3 & $2.048,63$ & $1.562,83$ & 505,61 & 0 \\
\hline
\end{tabular}

\section{Model 1}

Berdasarkan hasil permodelan menggunakan standar deviasi, luas lahan sawah sangat direkomendasikan untuk LP2B seluas 234,88 ha. Pada model 1 seluruh lahan sawah sangat rekomendasi berada di Kecamatan Mengwi, yaitu tersebar di 4 (empat) subak, antara lain Subak Cangi, Uma Tegal, Balangan dan Dukuh.

Lahan sawah rekomendasi seluas 1489,91 ha, yang seluruh lahannya berada di Kecamatan Mengwi. Lahan sawah rekomendasi tidak terdapat di Kecamatan Kuta Utara. Lahan sawah rekomendasi bersyarat seluas $2.969,50$ ha berada di seluruh subak di Kecamatan Kuta Utara dan tersebar di seluruh subak di Kecamatan Mengwi, kecuali Subak Uma Tegal dan Balangan. Penelitina ini sangat membantu dalam melengkapi Peraturan Daerah (Perda) No 8 tahun 2019 tentang Perlindungan
Perlindungan Lahan Pertanian Pangan Berkelanjutan.

Lahan sawah yang tidak direkomendasikan seluas 270,81 ha. Lahan sawah subak yang tidak direkomendasikan di Kecamatan Kuta Utara lokasinya tersebar di seluruh subak seluas 135,67 ha dan di Kecamatan Mengwi seluas 132.75 ha. Peta model 1 zonasi LP2B disajikan pada Gambar 2.

Perda Kabupaten Badung Nomor 26 Tahun 2013 tentang RTRW Kabupaten Badung tahun 2013 - 2033, pada pasal 81 ayat 2 mengenai ketentuan umum Peraturan Zonasi Kawasan Peruntukan Pertanian budidaya tanaman pangan mengatakan bahwa penetapan pencapaian target luas Lahan Pertanian Pangan Berkelanjutan sekurang-kurangnya 90\% (sembilan puluh persen) dari luas lahan pertanian pangan yang ada. Luas lahan pertanian pangan yang ada di Kecamatan Kuta Utara tahun 


\section{KARTIKA DEWI OKTAFIANTI et al. Pemetaan Kawasan Lahan Pertanian Pangan...}

2019 yaitu 850,15 ha dan Mengwi yaitu

4.117,07 ha, hal ini berarti target luas LP2B

di Kecamatan Kuta Utara dan Mengwi sekurang-kurangnya 765,13 ha dan $3.705,36$ ha.

Luas lahan sawah yang direkomendasikan sebagai LP2B di Kecamatan Kuta Utara pada Model 1 hanya mencapai $84,04 \%(714,48$ ha) dari lahan sawah yang ada (850,15 ha). Hal ini tidak sesuai ketentuan dalam Perda Kabupaten Badung Nomor 26 Tahun 2013 yang menetapkan target luas LP2B sekurangkurangnya $90 \%$ dari luas lahan pertanian pangan yang ada.
Lahan sawah yang direkomendasikan sebagai LP2B di Kecamatan Mengwi (sangat direkomendasikan, direkomendasi dan rekomendasi bersyarat) pada Model 1 luasnya mencapai $96,80 \%(3.979,83$ ha $)$ dari lahan sawah yang ada (4117,07 ha). Hal ini berarti luas lahan yang direkomendasikan sebagai LP2B pada Model 1 sesuai dengan Perda Kabupaten Badung Nomor 26 Tahun 2013 yaitu target luas Lahan Pertanian Pangan Berkelanjutan sekurang-kurangnya $\quad 90 \%$ dari lahan pertanian pangan yang ada.

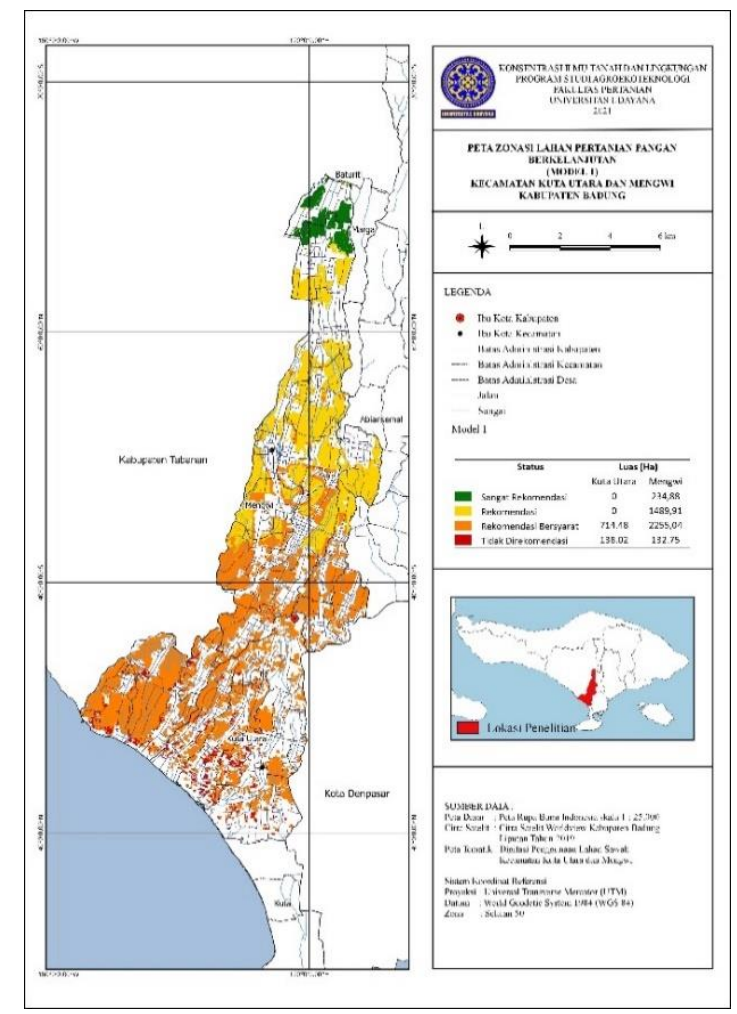

Gambar 2. Peta Model 1 Zonasi Lahan Pertanian Pangan Berkelanjutan 
Agrotrop : Journal on Agriculture Science, 11 (2): 176 - 188 (2021)

Model 2

Lahan sawah sangat direkomendasikan sebagai LP2B pada Model 2 seluas 939,76 ha, seluruh lahannya terletak di Kecamatan Mengwi yang tersebar di 21 subak. Lahan sawah rekomendasi pada model 2 luasnya 1101,52 ha yang seluruh lahannya berada di Kecamatan Mengwi, tersebar di 30 subak. Lahan sawah rekomendasi di Kecamatan Kuta Utara luasnya 0 ha.

Lahan sawah yang berstatus rekomendasi bersyarat pada model 2 seluas 2048,49 ha. Lahan sawah rekomendasi bersyarat di Kecamatan Kuta Utara luasnya 484,69 ha berada di seluruh subak di Kuta Utara. Lahan sawah rekomendasi bersyarat di Mengwi luasnya 1563,80 ha, tersebar di 30 subak di kecamatan tersebut.

Luas lahan sawah yang tidak direkomendasikan sebagai LP2B adalah 875,33 ha. Lahan sawah subak yang tidak direkomendasikan di Kecamatan Kuta Utara memiliki luas 365,46 ha, tersebar di seluruh subak. Lahan sawah yang tidak direkomendasikan di Kecamatan Mengwi seluas 507,51 ha berada di 25 subak. Peta model 2 zonasi LP2B disajikan pada Gambar 3.

Luas lahan sawah yang direkomendasikan sebagai LP2B di Kecamatan Kuta Utara pada Model 2 hanya mencapai 57,01 \% (484,69 ha) dari lahan sawah yang ada (850,15 ha). Hal ini tidak sesuai ketentuan dalam Perda Kabupaten Badung Nomor 26 Tahun 2013 yang menetapkan target luas LP2B sekurangkurangnya $90 \%$ dari luas lahan pertanian pangan yang ada.

Lahan sawah yang direkomendasikan sebagai LP2B di Kecamatan Mengwi pada Model 2 (sangat direkomendasikan, direkomendasikan dan rekomendasi bersyarat) luasnya mencapai 87,56\% (3.979,83 ha) dari lahan sawah yang ada (4117,07 ha). Hal ini berarti luas lahan yang direkomendasikan sebagai LP2B pada Model 2 belum sesuai dengan Perda Kabupaten Badung Nomor 26 Tahun 2013 bahwa target luas Lahan Pertanian Pangan Berkelanjutan sekurang-kurangnya $90 \%$. 


\section{KARTIKA DEWI OKTAFIANTI et al. Pemetaan Kawasan Lahan Pertanian Pangan...}

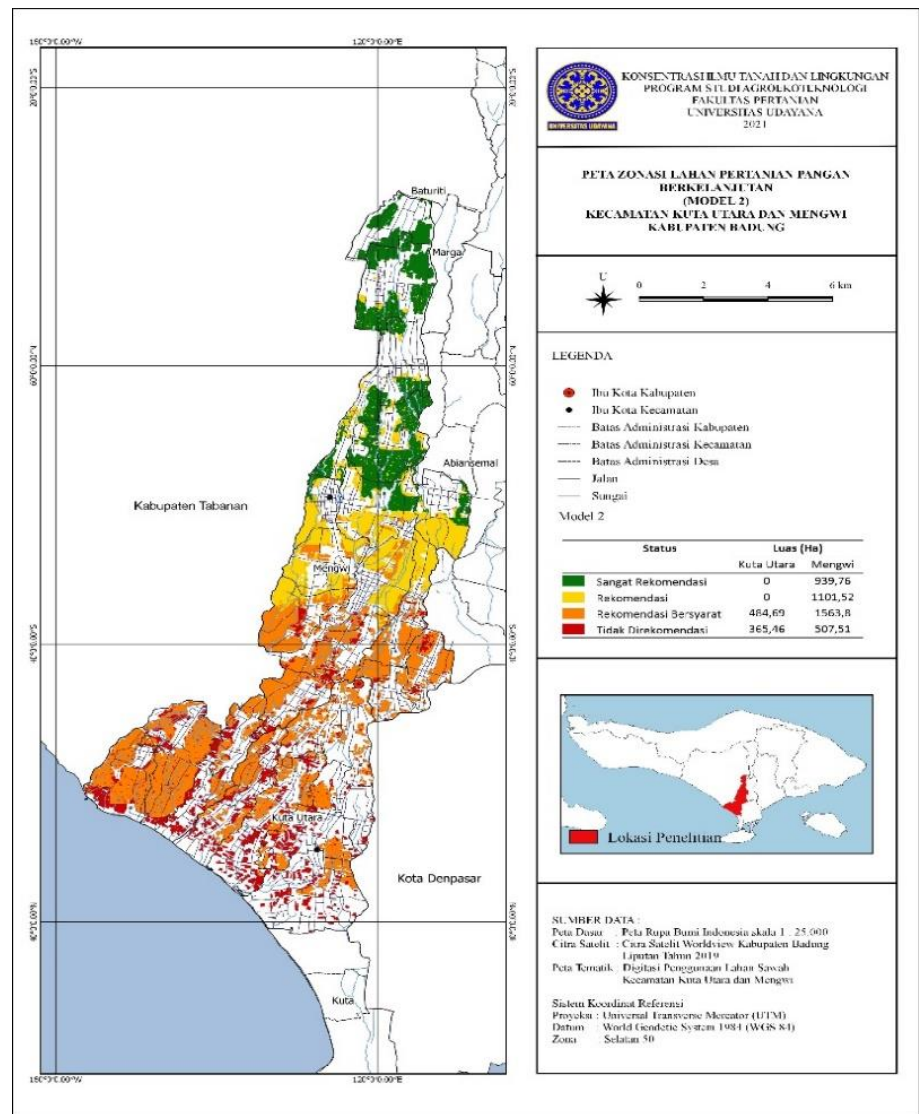

Gambar 3. Peta Model 2 Zonasi Lahan Pertanian Pangan Berkelanjutan

\section{Model 3}

Lahan sawah yang sangat direkomendasikan sebagai LP2B pada Model 3 seluas 2048,63 ha, seluruh lahannya berada di Kecamatan Mengwi. Lahan sawah subak sangat rekomendasi lokasinya tersebar di 34 subak di Kecamatan Mengwi.

Luas lahan sawah rekomendasi LP2B pada model 3 yaitu 2047,53 ha. Lahan sawah rekomendasi LP2B di Kecamatan Kuta Utara memiliki luas 484,69 ha, tersebar di seluruh subak di kecamatan tersebut. Sedangkan lahan sawah rekomendasi LP2B di Kecamatan Mengwi seluas 1562,83 ha, berada di seluruh subak di Mengwi kecuali Subak Karang Dangka, Dukuh, Uma Tegal dan Balangan.

Lahan sawah rekomendasi bersyarat pada model 3 luasnya yaitu 873,39 ha. Lahan sawah rekomendasi bersyarat di Kecamatan Kuta Utara luasnya 365,46 ha yang berada di seluruh subak di kecamatan tersebut. Lahan rekomendasi bersyarat di Kecamatan Mengwi seluas 505,61 hatersebar di 25 subak. Lahan sawah tidak 
direkomendasikan sebagai LP2B seluas 0 ha, baik di Kecamatan Kuta Utara maupun Mengwi tidak terdapat subak yang termasuk lahan sawah tidak direkomendasikan. Peta model 3 zonasi LP2B disajikan pada Gambar 4.

Luas lahan sawah yang direkomendasikan sebagai LP2B di Kecamatan Kuta Utara pada Model 3 (sangat rekomendasi, rekomendasi dan rekomendasi bersyarat) mencapai $100 \%$ dari lahan sawah yang ada (850,15 ha). Hal ini berarti sesuai dengan Perda Kabupaten Badung Nomor 26 Tahun 2013 yang menetapkan target luas LP2B sekurang- kurangnya $90 \%$ dari luas lahan pertanian pangan yang ada.

Lahan sawah yang direkomendasikan sebagai LP2B di Kecamatan Mengwi pada Model 3 (sangat direkomendasikan, direkomendasikan dan rekomendasi bersyarat) luasnya mencapai $100 \%$ dari lahan sawah yang ada (4117,07 ha). Hal ini berarti luas lahan yang direkomendasikan sebagai LP2B pada Model 2 sesuai dengan Perda Kabupaten Badung Nomor 26 Tahun 2013 bahwa target luas Lahan Pertanian Pangan Berkelanjutan sekurang-kurangnya $90 \%$.

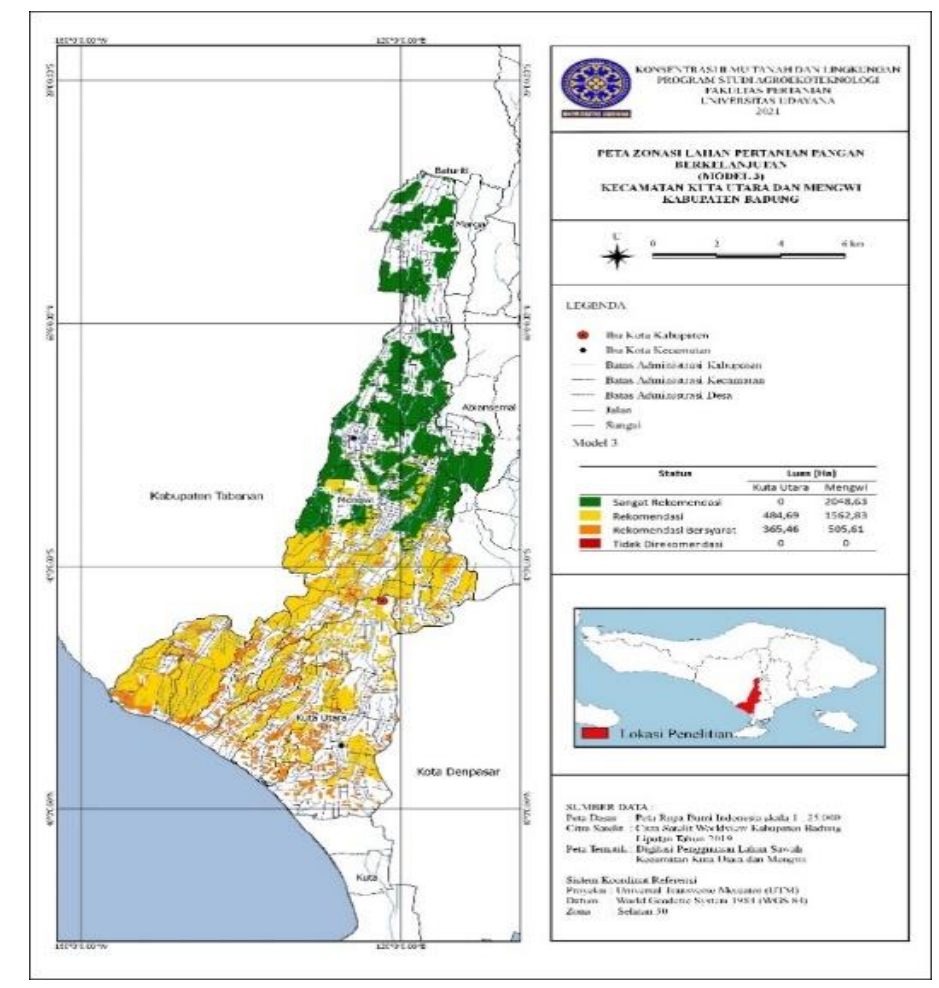

Gambar 4. Peta Model 3 Zonasi Lahan Pertanian Pangan Berkelanjutan 


\section{KARTIKA DEWI OKTAFIANTI et al. Pemetaan Kawasan Lahan Pertanian Pangan...}

\section{SIMPULAN}

Luas lahan sawah hasil tahun 2019 yang ada di Kecamatan Kuta Utara dan Mengwi 4967,22 ha. Kecamatan Kuta Utara seluas 850,15 ha dan di Kecamatan Mengwi seluas 4117,07 ha. Klasifikasi LP2B dalam 3 (tiga) pemodelan di Kecamatan Kuta Utara yaitu: Baik Model 1,2,3 tidak ada lahan sawah sangat direkomendasikan. Demikian pula model 1 dan 2 tidak ada yang direkomendasikan, sedangkan model 3 (484,69 ha); Lahan sawah rekomendasi bersyarat 714,48 ha (model 1), 484,69 ha (model 2) dan 365,46 ha (model 3); Lahan sawah tidak direkomendasikan 138,02 ha (model 1), 365,46 ha (model 2) dan 0 ha (model 3). Klasifikasi LP2B dalam 3 (tiga) pemodelan di Kecamatan Mengwi yaitu lahan sawah sangat direkomendasikan 234,88 ha (model 1), 939,76 ha (model 2) dan 2048,62 ha model 3); Lahan sawah rekomendasi 1489,91 ha (model 1), 1101,52 ha (model 2) 1562,83 ha (dan model 3); Lahan sawah rekomendasi bersyarat pada 2255,04 ha (model 1)), 1563,80 ha (model 2) dan 505,61 ha (model 3); serta lahan sawah tidak direkomendasikan 132,75 ha (model 1), 507,51 ha( model 2)) dan 0 ha (model 3). Peta dan data luas zonasi Lahan Pertanian Pangan Berkelanjutan berbasis SIG pada
Model 3, baik untuk Kecamatan Kuta Utara, maupun mengwi dapat digunakan untuk menunjang Perda Kabupaten Badung Nomor 8 Tahun 2019 tentang Perlindungan LP2B. Perlu dilakukan penelitian pemetaan rekomendasi LP2B lebih lanjut untuk Kecamatan lainnya dengan menggunakan metode klasifikasi numerik.

\section{DAFTAR PUSTAKA}

Badan Pusat Statistik. (2019). Laju Pertumbuhan Penduduk Menurut Provinsi. BPS. Jakarta Pusat

Badan Pusat Statistik. (2019). Luas Lahan Menurut Penggunaan. BPS Kabupaten Badung. Mangupura.

Badan Pusat Statistik. (2020). Provinsi Bali Dalam Angka 2020. BPS Provinsi Bali. Denpasar

Feronika, Lanya I., \& Nuarsa, I. W. (2017). Aplikasi Remote Sensing dan GIS Untuk Pemetaan dan Penyusunan Informasi Sumber Daya Subak di Kecamatan Mengwi Kabupaten Badung. Jurnal Agroroekoteknologi Tropika. Volume 7(1):2301-6515.

Lanya, I., Subadiyasa, N. N., Sardiana, I. K. \& Ratna Adi, I. G. P. (2015). Numerical Classification, Subak Zoning and Land Transfer Function Rice Field in The Province of Bali based on Remote Sensing and GIS. Elsevier Journal of Procedia Environmental Science, Vol. 24 (2015): 47-55.

Lanya, I., \& Subadiyasa, N. N. (2016). Role of Remote Sensing and Geographyc Information System Mapping for Protected Areas Land Rice Field Subak, Buffer Zones, and Area Conversion (Case Studies In Gianyar 
Agrotrop : Journal on Agriculture Science, 11 (2): 176 - 188 (2021)

Regency, Bali Province). IOP Conf. Series: Earth and Environmental Science, Volume 47 (1) p. 012037.

Peraturan Daerah Kabupaten Badung (2013). Rencana Tata Ruang Wilayah Kabupaten Badung Tahun 2013 2033. Lembaran Daerah Kabupaten Badung Tahun 2013, Nomor 26. Mangupura.

Peraturan Daerah Kabupaten Badung. (2019). Perlindungan Lahan Pertanian Pangan Berkelanjutan (Lembaran Daerah Kabupaten Badung tahun 2019 No 8. Noreg Peraturan Daerah Kabupaten Badung Provinsi Bali.

Suarjaya, D. G., Lanya, I., \& Ratna Adi, I. G. P. (2017). Aplikasi Remote Sensing dan Sig Untuk Pemetaan dan Informasi Sumberdaya Lahan Subak Sawah di Kecamatan Kuta dan Kuta Utara, Kabupaten Badung. E-Jurnal Agroekoteknologi Tropika, Volume 6 (3): $239-248$.

Sugiyono. (2011). Metode Penelitian Kuantitaif Kualitatif dan $R \& B$. Bandung: Alfabeta.

Sutanto. (1994). Penginderaan Jauh. Gadjah Mada University Press Yogyakarta. Jilid 2

Trigunasih, N. M. (2017). Model Klasifikasi Numerik Spasial Kawasan Lahan Pertanian Pangan Berkelanjutan di Kabupaten Badung dan Kota Denpasar. Disertasi. Universitas Udayana. Denpasar. 